\title{
TWO HERMENEUTICAL TENSIONS IN EVANGELICAL FEMINISM'
}

\author{
Vern S. Poythress \\ Westminster Theological Seminary \\ Correspondence: vpoythress@wts.edu
}

\begin{abstract}
This article shows that there are at least two key hermeneutical tensions in evangelical feminist interpretation of the Bible. The first hermeneutical tension concerns the issue of readers' prejudices. Feminists remind us that readers are always disposed to read texts against the background of their own expectations, customs, and world views. And, the second hermeneutical tension, namely the tension over the nature of the actual practices of the first century church. Evangelical feminists have tended to give different answers depending on the passage that they are interpreting. In sum, feminism in its hermeneutical principles alerts us to the role of reader prejudice and social background in understanding texts.
\end{abstract}

KEYWORDS: Hermeneutic, feminist, prejudice, Christian

\begin{abstract}
ABSTRAK: Artikel ini menunjukkan bahwa setidaknya ada dua kunci ketegangan hermenetik dalam penafsiran feminis evangelikal terhadap Alkitab. Ketegangan hermeneutik pertama menyangkut masalah prasangka pembaca. Kaum feminis mengingatkan kita bahwa para pembaca selalu cenderung membaca teks-teks dengan latar belakang harapan, kebiasaan, dan pandangan dunia mereka sendiri. Dan, ketegangan hermeneutik kedua, yaitu ketegangan atas sifat praktik sebenarnya dari gereja abad pertama. Para feminis evangelis cenderung memberikan jawaban yang berbeda tergantung pada bagian yang mereka tafsirkan. Singkatnya, feminisme dalam prinsip-prinsip hermeneutiknya mengingatkan kita pada peran prasangka pembaca dan latar belakang sosial dalam memahami teks.
\end{abstract}

KATA KUNCI: Hermeneutik, feminis, prasangka, Kristen

\footnotetext{
An earlier version of this paper was presented at the Easter Regional Meeting of the Evangelical Theological Society, April 5, 1991.
} 
I should like to show that there are at least two key hermeneutical tensions in evangelical feminist interpretation of the Bible. Moreover, I think that these tensions are ultimately resolvable only by moving beyond feminist readings of the relevant biblical texts.

\section{Reader Prejudice}

The first hermeneutical tension concerns the issue of readers' prejudices. Feminists remind us that readers are always disposed to read texts against the background of their own expectations, customs, and world views. Moreover, readers have a natural disposition to find in texts confirmations rather than repudiations of their own prejudices.

What does this principle imply when we use it with respect to readers who are men or women? A number of feminists try to show that the Bible has in the past been read prejudicially. The argument goes as follows. In traditional societies most men were disposed to read texts as supportive of their own more prominent social roles. In particular, men read the Bible as supportive of their roles. Moreover, in prior centuries of church history, the expert readers of the Bible were primarily men. This history of reading, it may then be alleged, explains the dominance of complementarian rather than feminist readings of the Bible in the church. ${ }^{2}$ Such readings, it is argued, arise from male bias rather than from the texts themselves.

But when we apply these insights to the first century church, the results militate against a feminist understanding of the Bible. In the first century the society around the church, both Jewish and pagan, was predominantly patriarchal. Hence many Christians would have carried into the church some of the patriarchal dispositions of the surrounding culture. What did these readers understand when they read their Bibles? What did they do with the standard passages such as Genesis 1-2; Galatians 3:28; 1 Corinthians

2 I use the word "complementarian" to describe any of a spectrum of positions advocating the irreversibility of male and female roles in the family and in church leadership. For a mainstream articulation of a complementarian position, see John Piper and Wayne Grudem, eds., Recovering Biblical Manhood and Womanhood (Wheaton, IL: Crossway Books, 1991); Wayne Grudem, Evangelical Feminism E Biblical Truth: An Analysis of More Than One Hundred Disputed Questions (Wheaton, IL: Crossway, 2012). The evangelical literature advocating feminism or egalitarianism is extensive, but we may cite as prime representatives Aida Besançon Spencer, Beyond the Curse: Women Called to Ministry (Nashville, TN: Nelson, 1985); Gilbert G. Bilezikian, Beyond Sex Roles: A Guide for the Study of Female Roles in the Bible (Grand Rapids: Baker, 1985); Alvera Mickelsen, ed., Women, Authority and the Bible (Downers Grove, IL: InterVarsity, 1986); Patricia Gundry, Heirs Together: Mutual Submission in Marriage (Grand Rapids: Zondervan, 1988); idem, Neither Slave Nor Free: Helping Women Answer the Call to Church Leadership (San Francisco: Harper \& Row, 1987). The organization Christians for Biblical Equality International (https:/www.cbeinternational.org/) publishes a journal Mutuality and other materials. On the complementarian side is the Council for Biblical Manhood and Womanhood (https://cbmw.org/), with a journal Eikon: A Journal for Biblical Anthropology, and other materials. There are also people who have tried to stake out intermediate positions. 
11:2-16; 14:34-35; Ephesians 5:21-6:9; Colossians 3:18-4:1; 1 Timothy 2:8-15; 3:1-13; 5:1-2; 5:3-16; Titus 1:5-9; 2:2-5; 1 Peter 3:1-7? We do not know in detail. But feminists themselves are well aware of just how difficult it may be for Christians to move out of hide-bound ways of thinking. Given this knowledge, it is inevitable that a crucial admission will be forthcoming: by and large, many people in the early church read the key passages in more or less the same way that they have always been read in subsequent centuries within patriarchal or complementarian cultures, namely in a complementarian rather than feminist way.

In the NT, there are too many passages that never "drop the second shoe." The passages say that women must submit to their husbands. But they never say explicitly that husbands must submit to their wives. They explicitly instruct Timothy and Titus about appointing men as elders, but they never explicitly mention the possibility of women elders. They draw some conclusions about restrictions on women's behavior from citations of the creation narrative, but do not mention parallel restrictions on men's behavior (1 Timothy 2:12-14; 1 Corinthians 14:33-36; possibly 1 Corinthians 11:3-16, though there is some apparent parallelism here between men and women). These passages are obviously sexually asymmetric. They say different things concerning the two sexes. When complementarians read these passages, their complementarian leanings may be refined and purified. But they would hardly be overthrown and replaced by outright feminism.

\section{First Century Social Practice}

The difficulties are increased when we add a second hermeneutical tension, namely the tension over the nature of the actual practices of the first century church. Was the first century church fundamentally egalitarian/ feminist in its social practices or not? Evangelical feminists have tended to give different answers depending on the passage that they are interpreting.

First, with respect to some passages like 1 Peter 3:1-7 they have often argued that wide-spread patriarchalism in first century culture produced an atmosphere in which it was expedient for women to take an asymmetric submissive role. Peter advises women to conform to such a role in order that the gospel may be adorned and not reproached.

Second, with respect to other passages, such as Romans 16:1, Acts 21:9, and 1 Timothy 2:9-15, they have sometimes argued that women in the early church could and did fill virtually any role in principle. For example, with respect to 1 Timothy 2:9-15 it may be said that Paul lays down rules binding only at Ephesus for a limited time, in order to correct a temporary disorder among some of the women. Supposedly, 1 Timothy 2:9-15 does 
not in any general way forbid first-century Christian women from teaching or holding the office of elder.

But feminists cannot easily have it both ways. Was it or was it not true that women enjoyed virtually the same role relationships as men did within the first century church? There are several possible answers, but all of them create further problems for feminist interpretation, as we shall see.

One theoretically possible answer is that the social situation differed markedly from place to place in the Roman Empire. But by the first century A.D. wide-spread Hellenization had created a considerable similarity in culture throughout the Roman Empire. Though differences remained between Roman, Greek, and Judaic culture, all three cultures expected predominantly male leadership in society, and all three understood women to play a subordinate role in the family. The data in the NT letters tend to confirm the supposition that the fundamental social situations were similar throughout the Roman Empire. For example, 1 Corinthians 11:16 indicates that the differences between churches are not so great that they would make irrelevant an appeal to the prevailing practice of the churches elsewhere. Titus 1:5 indicates that the Letter to Titus is discussing principles applicable throughout Crete and not merely in one local church. 1 Timothy focuses on troubles at Ephesus (1 Timothy 1:3), but 1 Timothy 3:14-15 indicates that the principles articulated in the Letter have much wider bearing. The Letter to the Ephesians was possibly a circular letter, intended to be distributed through Asia Minor.

Hence, it is most likely that similar social circumstances prevailed in the great majority of churches in the first century. What were those circumstances? Several alternatives are possible in theory.

(1) The first possibility is that in first century practice Christian marriages and Christian church life involved feminist role equality and interchangeability. In principle, all roles were viewed as open to both men and women, though in practice women had fewer opportunities for education and experience such as would qualify them for major roles of social leadership. Hence, it is likely that more men than women were involved in leadership roles, but there were a scattering of women in such roles. In the family and the church the power of the gospel effectually liberated women from the strictures placed on them in the surrounding non-Christian culture.

(2) Second, it is possible that in first century practice Christian marriages and Christian church life involved complementarian differentiation of roles. Elders and official teachers were expected to be men, not women, 
and women were expected to submit to their husbands in marriage. Husbands were to love their wives, in a pattern imitating Christ's love and leadership. But this injunction or similar injunctions was not ordinarily understood immediately as leading to "equal" leadership in the family, any more than Christ's love for the church meant surrendering his authority over the church.

(3) Third, Christian marriages were complementarian, while the church community was feminist (displaying no sexual role differentiation).

(4) Fourth, Christian marriages were feminist (displaying no sexual role differentiation), while the church community was complementarian.

Option (4) is the least likely. If the gospel contains inherently a feminist leaven within it, such leaven would most likely leaven the church first, then other societal institutions. I know of no feminist who advocates option (4).

Option (3) is not so likely either. As I have argued elsewhere, ${ }^{3}$ built-in analogical relations between the church and the family make it hard to envision contrary practices taking place in the two spheres.

The principal options, then, are (1) and (2). But option (1) is demonstrably incorrect. For one thing, Christians would have had to break with the practices of the surrounding culture. The power of the gospel does make such breaks possible. But they are seldom easy when a whole community is involved. In the Corinthian church and other immature churches, we would expect that some immature Christians would resist such a break with patriarchal practices. Surely such a break would have potentially generated as much turmoil in the first century as it does in the twentieth century and twenty-first century evangelical church. If anything, first century culture was more entrenched in patriarchy than is post-industrial America. Similar struggles were recorded when the church broke the confines of its Jewish origins, when it dealt with emperor worship, and when it struggled with what to do with food offered to idols.

Hence, a radical break with respect to sexual customs would have precipitated struggle. If the church had to struggle with such a break, why is there no mention of the struggle in the pages of the NT? In fact, the situation is even more troublesome. Why do the apostolic letters, when they talk about men and women, so frequently use language that complementarians would exploit in their favor? Feminists complain in our day about how Ephesians 5:22-33; Colossians 3:18-19; 1 Peter 3:1-7; etc. are "misunderstood"

\footnotetext{
Vern S. Poythress, "The Church as Family: Why Male Leadership in the Family Requires Male Leadership in the Church as Well," in John Piper and Wayne Grudem, eds., Recovering Biblical Manhood and Womanhood (Westchester, IL: Crossway Books, 1991).
} 
by complementarians. Would not such passages be just as easily "misunderstood" in the first century? Feminists complain about how hard it is to dislodge male chauvinism, a chauvinism picked up from our society, a chauvinism whose framework makes it impossible rightly to understand Ephesians 5:22-33; etc. Was not such chauvinism just as much a factor in first century society? Does everyone in the church become magically freed from chauvinism so that they read all the NT passages in feminist fashion, without a word being said directly in that direction? Moreover, the asymmetric language in the NT provides suggestive evidence of the fact that there did remain some complementarianism in the church, just as sexually asymmetric language today is often symptomatic evidence of a residue of complementarianism.

In short, it is bound to be the case that there were complementarians within the first century church. And if there were, how would they ever be reformed out of their thinking when the surrounding culture was patriarchal, and when in addition they could quite easily understand a number of NT passages as being on their side? And if they were not reformed, wouldn't they have argued with those who were, and stirred up some controversy? And how can the apostles hope to deal with such a controversy by supplying so much apparently complementarian language in their letters?

We can still attempt to tinker with option (1), or to develop an option intermediate between (2) and (1). Some people might maintain that the great majority of marriages had male leadership, and the great majority of churches had only male elders, but that there were a few exceptions. Perhaps Priscilla and Aquila had a feminist marriage with equally shared leadership. Perhaps a few women like Phoebe (Rom 16:1) and Junia (Rom 16:7; many complementarians read "Junias," short for Junianus) occupied official ruling positions in the church. The four unmarried daughters of Philip who prophesied may have played a role equivalent to teachers. These exceptions then indicate the principial permissibility of a wider feminist practice today.

But this modified option is in fact less acceptable than either option (1) or option (2). For one thing, it rests on too many perhaps's. Was Phoebe really an elder? Or was she, more likely, a well-to-do patron involved in many useful projects? Was Junia(s) a man or a woman? And was he or she actually an apostle of Christ, or only well-respected among the apostles, or was he or she an apostle (= delegate) of a congregation (cf. 2 Corinthians $8: 23)$ ? Was prophesying equivalent to a teaching office, or did it, unlike 
teaching, refrain from exercising authority over men? ${ }^{4}$

Moreover, this modified option implies that feminist role relationships were on occasion effectually realizable in the first century without upsetting things very much. Suppose, then, that such roles were realizable and also ideal, as feminists claim. Yet most of the church did not actually adopt the feminist ideal. The apostles are then blameworthy for not explicitly exhorting their hearers to move in that direction. In fact, the apostles too often use language which, when heard by people with remaining complementarian tendencies, would result in blocking people from moving toward the ideal. In actual fact, the apostles in their letters do not do the job that feminists think should have been done. If we take this route, we are then setting ourselves up as critics of the ethical purity of the apostles' speech. Such an option is inconsistent with maintaining the Bible's view of the divine authority of the apostolic letters.

The same arguments apply, at least in part, to options (3) and (4). Feminist practice in either family or church is likely to lead to the same difficulties as would feminist practice in both spheres - though the evidence is more sparse if we can appeal to only one of the two social spheres.

We are left, then, with option (2). Within option (2), we confront some further questions. How would first century Christian readers interpret the key texts, given their social environment? Ephesians 5:21-6:9 would surely be interpreted not as a command for everyone to submit equally to everyone else, but for each person to submit to people with authority over him or her. For example, children submit to the parents, but parents do not submit to their children. When the role relationship calls for submission, submit. Such has been the understanding by nearly everyone outside of the influence of modern feminist philosophy, and such is bound to be the natural understanding in the first century church-given that option (2) correctly represents their actual social practice. Similar conclusions hold for Colossians 3:18-19 and 1 Peter 3:1-7. First Timothy 2:8-15 and 3:1-7 would quite naturally be understood as indicating, among other things, that the teachers and elders are to be men. Taken out of social and historical context, these passages as well as virtually any passage whatsoever are capable of sponsoring more than one meaning, as feminist interpreters have succeeded in demonstrating. But taken in context, they read naturally as injunctions not to overthrow existing social relations within the cultural practice of the

\footnotetext{
4 See Wayne A. Grudem, "Prophecy-Yes, But Teaching-No: Paul's Consistent Advocacy of Women's Participation Without Governing Authority," JETS 30 (1987), 11-23, for an argument that such prophesying is quite consistent with complementarian role differentiation. See also Grudem, Evangelical Feminism, 227-232.
} 
churches. Those social relations are to be transformed by Christian godliness, as Matthew 20:25-28 indicates. But long-term transformation is not the same as short-term overthrow.

\section{Authorial Intention in Relation to Readers' Impressions}

Up to this point we have focused mostly on the churches and how their members would most probably have understood the texts in question. But what did the apostles intend, and what did the texts actually mean? We need to invoke another principle:

Speakers and writers who desire to influence their audiences religiously and morally ought to take into account the way in which their audiences may misunderstand or abuse what they say, and to endeavor to take reasonable measures to head off such abuse.

When this principle is applied to the apostles, it implies that the apostles knew what they were doing when they wrote letters to people who had a patriarchal cultural background. The apostles must have known how such people would have interpreted asymmetric sexual language. Hence it follows that, by and large, the meaning that first century Christian would naturally have found in the apostolic letters is the meaning that the apostles intended and is the meaning that the texts themselves possess, when understood as the expression of apostolic intentions.

Let us state the point another way. To understand the apostolic letters properly, we must interpret grammatically and historically. We must understand the letters in their first century social and cultural context. Suppose that the apostles wanted to communicate a radical feminist ethic that would lead the church (gradually, to be sure) toward feminist practice. Would they have written as they did in the NT letters? By no means. Anyone with their understanding would see immediately that feminism needs to be made quite explicit in order to overcome the patriarchal prejudices of the readers. Their actual letters do the opposite at key places, when again and again they drift into asymmetric language. Such language would doubtless transform some of the problems in patriarchal practice into a more refined, moderate, and considerate form of complementarianism. But it would not have displaced complementarianism right away.

In sum, the apostles were not trying to inculcate radically feminist ethics as a short-term goal. By hermeneutical gymnastics we might fool ourselves for a while into believing that they had such a goal. But once we think of the apostolic letters as real communications to real people, the case collapses. The apostles wrote to be understood. In particular, they wrote 
ethical injunctions in order to set in motion ethical changes in people's lives. The letters set in motion a dynamics of social change in the readers. That social dynamics does not match twenty-first century feminist dreams. Given the first century context, the apostolic letters must be interpreted as tending sociologically to transform rather than abolish certain complementarian aspects of first century practice.

At least two evangelical feminists, Peter DeJong and Donald R. Wilson, agree with these conclusions. ${ }^{5}$ According to them, the apostles did not speak out against all sexual complementarianism for more or less the same reason that they did not speak out in favor of immediate abolition of slavery. The gospel penetrates societies and social institutions only gradually. Immediate revolution by brute force never cures the long-range problems, but only puts new masks on them. The gospel sets in motion a far more powerful transformation, a leaven that reinterprets, reevaluates, and transforms all social relations from the inside out.

In fact, suppose hypothetically that the apostles could have created an immediate sexual revolution, displacing all sexual complementarianism. The dislocations of the existing social order could have run so deep that disorders would follow. And in situations of wide-spread social disorder, the socially disadvantaged - women, children, poor people, etc. - are always exposed to suffering.

Hence the apostolic injunctions assume as their context the existing social dimensions of the patriarchal cultural traditions around them. They counsel everyone involved to serve the Lord within the existing order, but also to transform it with new love, through the Holy Spirit. All service, even the service of the slave, is filled with significance and dignity, because it is offered to the Lord (Colossians 3:23-24; Ephesians 6:7-8). The apostles wisely adapted their instructions to the concrete context of their addressees. They gave their addressees exactly what they most needed to live in Christ-like peace, dignity, and freedom within the limitations of their circumstances. Likewise, Jesus appointed as apostles twelve men, and did not immediately break with Jewish tradition concerning the patriarchal headship of the twelve OT tribes. According to DeJong and Wilson, only in the long run does it become evident that the implications of the gospel break the bounds of complementarianism.

Note also that the patriarchy of OT and NT cultures did not necessarily exclude women from ever occupying a role of social or religious prominence.

Peter DeJong and Donald R. Wilson, Husband \& Wife: The Sexes in Scripture and Society (Grand Rapids: Zondervan, 1979). 
Proverbs 31 illustrates the breadth of scope possible even in ordinary circumstances. Moreover, Esther was a queen. Miriam, Deborah, Huldah, and Isaiah's wife were prophetesses (Exodus 15:20; Judges 4:4; 2 Kings 22:14; Isaiah 8:3). Deborah judged Israel (though this role functioned to rebuke the inadequate male leaders: Judges 4:8-9; Isa 3:12). Salome Alexandra, wife of Alexander Jannaeus, ruled over the Jews from 76 to 67 B.C. Women played an important role in Jesus' earthly ministry and as witnesses to his resurrection. Lydia, Priscilla, Phoebe, and others obviously had significant roles. ${ }^{6}$ Such things must be seen as part of the social background of the biblical writings. Doubtless the recognition of such roles for women tempered and mollified the complementarian views of many in the church. But the resulting views were still identifiably complementarian, not feminist.

When we read the biblical writings bearing in mind the social background of the readers, many of the exegetical disputes between feminists and complementarians resolve themselves. Christian marriages were complementarian. The relevant texts were understood against this background. Ephesians 5:22-33 does not mean that first century husbands are to submit to their wives in a fashion exactly matched to the submission of wives to their husbands. Ephesians 5:22-33; Colossians 3:18-19; and 1 Peter 3:1-7 instruct Christian married people to live together with one another in a manner that superficially is not is disharmony with surrounding social expectations. The roles are not reversible.

Moreover, there were close analogies between the church and the ordinary family. ${ }^{7}$ Hence there is a presumption in favor of the assumption that the recognized church governors or "fathers" were men. In the light of the male language in 1 Timothy 3:1-7 and Titus 1:6, there is no reason to think that Paul, Timothy, or Titus deviated from social practice that was normal with respect to formal leadership in the synagogue. They appointed men elders. And such a practice was apparently wide-spread (1 Timothy 3:1415; Titus 1:5; Acts 14:23). Hence, purely on the basis of general historical inference, it is exceedingly unlikely that Phoebe was an elder or that Junia(s) was a woman apostle (Romans 16:1, 7). On the other hand, prophetesses were known and accepted from OT times, and so there is nothing in Acts 21:9 that would radically disrupt complementarian expectations of the times.

Now consider 1 Timothy 2:9-15. Against the background of social expectations like these, 1 Timothy 2:9-15 has wider relevance than merely

\footnotetext{
6 See further Thomas R. Schreiner, "The Valuable Ministries of Women in the Context of Male Leadership: A Survey of Old and New Testament Examples and Teaching," Recovering Biblical Manhood and Womanhood, 209-224.

7 See Poythress, "The Church as Family."
} 
at Ephesus. Disorders among women doubtless occasioned this passage. But Paul enjoined a submissiveness on the part of women such as would be relevant in other churches as well. Consider how Timothy would naturally interpret a passage like this one. Timothy reads this text as a participant in a patriarchal society, and he knows that complementarian practices extend into the church. In the next chapter he is instructed on appointing male elders. In addition, 1 Timothy 3:15 generalizes beyond the immediate circumstances in Ephesus. It is natural for Timothy to see a broader applicability for this passage. Moreover, how would Timothy be expected to detect some of the exegetical oddities that feminists have sometimes postulated for this text? "I do not permit" in v 12 is not merely an observation about what Paul may do one or more times, but what Timothy is expected to do. $\alpha \dot{v} \theta \varepsilon \nu \tau \varepsilon \tilde{i} v$ in $\mathrm{v} 12$ is correctly translated as "to have authority over" - not because the Greek word cannot even in theory mean or connote anything else, but because this meaning is the obvious one for any reader in Timothy's situation.

Again, it has been suggested that $\mathrm{v} 13$ is placed where it is because there was a heresy at Ephesus that taught that Eve was created first. But what does the word "For" ( $\gamma \grave{\alpha} \varrho)$ at the beginning of the verse do? V 13 is not a refutation of or answer to a heresy not mentioned, but a reinforcement that supplies a reason for the practice in $\mathrm{v} 12$. At least that is how Timothy would naturally read it, even if there is some hypothetical unmentioned feminist heresy at Ephesus. ${ }^{8}$

\footnotetext{
8 For further discussion on 1 Tim 2:8-15, see Andreas Köstenberger, Thomas R. Schreiner, and H. Scott Baldwin, eds., Women in the Church: A Fresh Analysis of 1 Timothy 2:9-15 (Grand Rapids, MI: Baker Books, 1995); Douglas J. Moo, "1 Timothy 2:11-15: Meaning and Significance," Trinity Journal 1 NS (1980), 62-83; Philip B. Payne, “Libertarian Women in Ephesus: A Response to Douglas J. Moo's Article, '1 Timothy 2:11-15: Meaning and Significance,' " Trinity Journal 2 NS (1981), 169-97; Douglas J. Moo, "The Interpretation of 1 Timothy 2:11-15: A Rejoinder," Trinity Journal 2 NS (1981), 198-222; Douglas J. Moo, “What Does It Mean Not to Teach or Have Authority Over Men?" Recovering Biblical Manhood and Womanhood, 179-93; Catherine C. Kroeger, "Ancient Heresies and a Strange Greek Verb," Reformed Journal 29 no. 3 (1979), 12-15; Richard Kroeger and Catherine Kroeger, "May Women Teach? Heresy in the Pastoral Epistles," Reformed Journal 30 no. 10 (1980), 14-18; no author, "1 Timothy 2:121-a Classicist's View," Women, Authority and the Bible, 225-44; Bruce Barron, "Putting Women in Their Place: 1 Timothy 2 and Evangelical Views of Women in Church Leadership," JETS 33 (1990), 451-59. In this article I cannot re-cover all the exegetical ground traversed by these articles.

My sympathies are with Moo and the complementarians, not only because of the detailed exegetical considerations that they bring to bear, but because of the general exegetical principle that the meaning that would be most obvious and most straightforward to the original readers within the original historical situation is to be preferred. Even if one postulates a feminist heresy at Ephesus with the particular textures suggested by the Kroegers (and this is a big "if"), such particulars do not significantly alter the import of 1 Tim 2:8-15. The women heretics, if there were some, are swept aside by means of a general charge to Timothy to see to it that Ephesian women conform to the general pattern of complementarian roles characterizing the churches at large (1 Tim 3:14-15). The supposed heretics are not singled out, but are grouped together with women generally.
} 
We could extend our observations to include other texts, but I trust that the point has been made sufficiently clear. When we take into account the complementarian practices in first century cultures and in first century church, feminist readings of the key texts cannot plausibly be sustained. Evangelical feminists are thus forced into the position articulated in 1979 by DeJong and Wilson in Husband \& Wife. According to this view, NT texts aim at transforming but not at immediately overthrowing patriarchal practice. One cannot directly appeal to any NT proof text in order to justify modern feminist sentiments. Only in the long run do the implications of the transforming forces in the NT become evident.

In their 1979 book, DeJong and Wilson nevertheless remained feminist in their ultimate allegiance because they thought that Genesis 1-3 supported feminism. But feminist interpretation of Genesis must collapse under the weight of the same hermeneutical tensions that we have already seen above. When one reads Genesis 1-3 against the background of the patriarchal culture that it addresses, the undeniably androcentric elements become evident: the creation of woman for man (to meet a need and to be a helper), the address to man first as the representative, the attention to Eve's role in child-bearing, and so on. ${ }^{9}$

In sum, feminism in its hermeneutical principles alerts us to the role of reader prejudice and social background in understanding texts. These principles force us to observe that the cultures of biblical times themselves had complementarian rather than feminist ideas and practices. Given this background, the texts communicate complementarian rather than feminist ideas to their original readers. Consequently, evangelical feminism is left in the long run with no texts on which it may base its social program. ${ }^{10}$

9 See D. A. J. Clines, “What Does Eve Do To Help? and Other Irredeemably Androcentric Orientations in Genesis 1-3," SBL paper, Dec. 7, 1987; published in What Does Eve Do to Help?: And Other Readerly Questions to the Old Testament (Sheffield, England: JSOT, 1990).

$10 \mathrm{Gal}$ 3:28 and the principles regarding the use of spiritual gifts are often cited as additional reasons for modern evangelical feminism. But to deduce feminism from these sources one must first read into them key feminist assumptions, namely that in principle creation and/or redemption negate all firm complementarian distinctions in roles. No such feminist assumptions can actually be found in any biblical text by grammatical-historical interpretation; on the contrary, modern complementarian interpretations easily show how the texts would in fact have been read in their original already complementarian cultures. See, for example, S. Lewis Johnson, Jr., "Role Distinctions in the Church: Galatians 3:28," in Recovering Biblical Manhood E Womanhood, 154-64. 